\title{
LINKING ANOMALOUS MOISTURE TRANSPORT AND DROUGHT EPISODES IN THE IPCC REFERENCE REGIONS
}

Anita Drumond, Milica Stojanovic, Raquel Nieto, Sergio Martin Vicente-Serrano, and luis Gimeno

An online catalog of drought episodes in the IPCC reference regions from 1980

to 2015 , with an analysis of the moisture transport during the most severe meteorological drought episodes, is described.

U nderstanding hydroclimatological processes is incredibly important, given the number of scientific disciplines involved and their association with several economic, social, and ecological impacts (Allen and Ingram 2002). Climate change is driving global temperature changes and affecting hydroclimatic processes via alterations to circulation (Vecchi and Soden 2007) and thermodynamic processes (Hirschi et al. 2011; Fu and Feng 2014).

AfFiliations: Drumond, Stojanovic, Nieto, AND GIMENOEnvironmental Physics Laboratory, Universidade de Vigo, Ourense, Spain; VICENTE-SERRANo-Instituto Pirenaico de Ecología, Consejo Superior de Investigaciones Científicas, Campus de Aula Dei, Zaragoza, Spain CORRESPONDING AUTHOR: Anita Drumond, anitadru@uvigo.es

The abstract for this article can be found in this issue, following the table of contents.

DOI:10.II75/BAMS-D-18-01II.I

In final form 16 March 2019

C)2019 American Meteorological Society

For information regarding reuse of this content and general copyright information, consult the AMS Copyright Policy.
Changes to both these process groups may increase aridity in large regions as a consequence of decreasing moisture supply to continental areas (Sherwood and Fu 2014). These changes could increase the severity and duration of extreme hydroclimatic events such as droughts (Vicente-Serrano 2016).

Droughts are extremely complex, with varied definitions causing problems in the conceptualization and monitoring of the phenomenon (Wilhite and Glantz 1985; García-Herrera et al. 2007; LloydHughes 2014; Marengo and Espinoza 2016). In general, drought is a temporal anomaly in relation to the long-term climate conditions (Wilhite and Pulwarty 2017) and is characterized by water availability below normal levels such that it cannot supply the existing demand (Redmond 2002). The effects of droughts may accumulate slowly over time, and expand over large regions, affecting different stages of the atmosphere water cycle (WMO 2012). Due to the different sectors affected by the droughts, these events can be classified into four major categories: meteorological, agricultural, hydrological, and socioeconomic (Wilhite and Glantz 1985). A meteorological drought is defined as below average precipitation for 
a certain period of time and may be combined with an increased potential evapotranspiration ${ }^{1}$ (Hanel et al. 2018). It is the primary cause of drought, and the remaining types may be considered as a consequence of the meteorological drought (Spinoni et al. 2014). A period with decreasing soil moisture adversely affecting agriculture defines an agricultural drought, while hydrological drought occurs when the water content of streams, lakes, reservoirs, and groundwater aquifers is below average and adversely affecting water users. Finally, socioeconomic drought occurs when the demand for an economic good surpasses its supply because of insufficient water supply during that time.

There are a number of studies that have linked drought with atmospheric circulation mechanisms, and also with thermodynamic processes related to soil water availability, latent and sensible fluxes, and hot weather (e.g., Feng et al. 2011; Miralles et al. 2019). Through empirical orthogonal function analysis, Dai (2011) verified that the second leading mode of variability in the global Palmer drought severity index (PDSI) is associated with El Niño-Southern Oscillation (ENSO). Vicente-Serrano et al. (2011) illustrated the regions in which ENSO causes general drought conditions, including large areas of North and South America, South Africa, the Sahel, and East Africa. Nevertheless, out of these areas, the effect of ENSO on triggering drought episodes is small and other circulation mechanisms at the hemispheric, regional, and local scales mostly explain drought. In some world regions like northern Eurasia, Europe, and North Africa; central and eastern Canada; and the Middle East there are not SST-drought-related impacts (Schubert et al. 2016). For example, largescale persistent anticyclones, driven by atmospheric blocking are the main driver of northern Eurasian droughts (Schubert et al. 2014). In Europe, droughts are related to Euro-Atlantic mechanisms such as the North Atlantic Oscillation, Scandinavian "blocking," and the "Atlantic ridge" (Kingston et al. 2015; Raymond et al. 2018). Nevertheless, no studies have analyzed the contribution of moisture sources and moisture transport processes to trigger drought episodes in depth at the global scale. The variations in moisture transport are usually related to a precipitation deficit over an area and, in some cases, to the drought occurrence (Liu et al. 2017).

Gimeno et al. (2012) provided a detailed review and comparison of the different techniques applied in the investigation of sources of moisture, including isotopes analysis, box models, and numerical water vapor tracers (WVTs). According to the authors, all of them provide useful information, although the results depend on the data used and assumptions made. For example, isotope analysis (e.g., Coplen et al. 2008) is dependent on the strength of the isotopic signal. The box models (e.g., Brubaker et al. 1993) can compute the moisture inflow and outflow given defined lateral boundaries, but there is no information concerning the physical processes that occur inside the box itself.

Concerning WVTs, there are Eulerian and Lagrangian approaches. On one hand, the Eulerian method (e.g., Cullather et al. 2000) is widely used due to its simplicity, but it is not simple to estimate the link between the precipitation over an area and its respective moisture source. On the other hand, the Lagrangian approach $^{2}$ (e.g., Stohl and James 2004, 2005) enables the tracking of air parcels, allowing the establishment of moisture source-receptor relationships in a more realistic way (Gimeno et al. 2012). For this reason, this method has been extensively applied in studies of the origin of the water that precipitates over a given region (e.g., Stohl and James 2004, 2005; Dirmeyer and Brubaker 2007; Sodemann et al. 2008; Scarchilli et al. 2011; Knippertz et al. 2013) and in the characterization of moisture transport worldwide (e.g., Drumond et al. 2008; Gómez-Hernández et al. 2013; Sorí et al. 2017; Drumond et al. 2016; Salah et al. 2018).

Applying the Lagrangian approach developed by Stohl and James (2004, 2005), Gimeno et al. (2010, $2012,2013)$ investigated moisture transport from the major oceanic sources to continental regions. Moreover, Nieto et al. (2014) identified the major climatic sources of moisture during 1980-2012 for two sets of continental climatic regions: one based on regions with similar late-twentieth-century mean climates and similar projected late-twenty-first-century precipitation changes, and the other based on the 21 reference regions (RRs) defined in the Fourth Assessment Report (AR4) of the Intergovernmental Panel on Climate Change (IPCC). They also analyzed the interannual variability of these sources and the role of some climate variability modes [including ENSO and the northern and southern annular modes (NAM and SAM, respectively)], although no drought analysis was provided.

Despite the abundance of studies regarding moisture transportation, relatively few studies have analyzed the contribution of moisture sources and moisture transport to drought episodes at the regional

\footnotetext{
${ }^{1}$ Potential evapotranspiration is the amount of evaporation that would occur if a sufficient water source was available.

${ }^{2}$ Lagrangian frame of reference: the observer follows a parcel as it moves through space and time.
} 


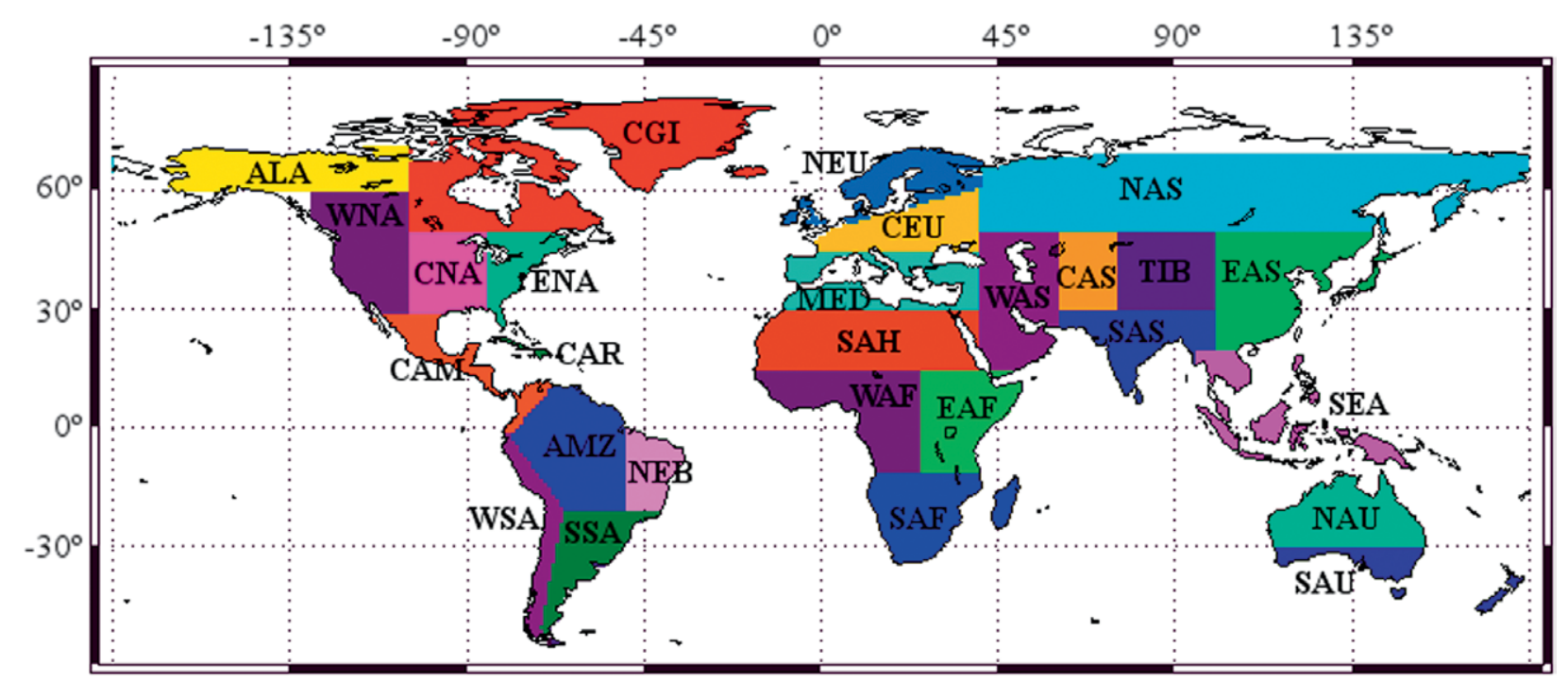

FIG. I. Continental RRs based on the geographical domains defined in the IPCC AR5.

scale (e.g., Drumond et al. 2016, 2017; Stojanovic et al. 2018a,b; Salah et al. 2018). While it has been proven that the absence of moisture transport from the sources toward the continents may even contribute to the persistence of droughts (Trigo et al. 2013), a systematic analysis of droughts and the associated moisture transport at the global scale is still missing from the literature. Pioneer studies at the regional scale, cited above, have suggested that droughts may be affected by anomalies in the moisture uptake by air masses over source regions and also by changes in the moisture transport to the target region. This makes a global assessment of these processes a real priority to determine drought mechanisms, with implications for drought early warning systems, monitoring, and forecasting.

This study describes an analysis that may be organized into two major goals: a) identification of the drought episodes at different standardized precipitation evapotranspiration index (SPEI) time scales $(1,6$, 12) over the terrestrial areas of $27 \mathrm{RRs}$ defined in the Fifth Assessment Report (AR5) of the IPCC (IPCC 2014) during 1980-2015, and b) a Lagrangian analysis of the role of the moisture transport anomalies from the respective climatological major moisture sources for the most severe meteorological drought event registered for each RR during the covered period. This global analysis considers the RRs defined at www .ipcc-data.org/guidelines/pages/ar5_regions.html and shown in Fig. 1. The results for all the regions are provided in an open catalog (http://ephyslab.uvigo .es/seth/). The major novelty of this manuscript with respect to the catalog published previously by Nieto et al. (2014) resides in the drought analysis, besides updating the references regions according to the IPCC AR5 and the extension of the climatological analysis to $1980-2015$.

The Southeastern South America (SSA) region is analyzed in more detail as an example of the information provided for each RR in the full catalog. The SSA comprises Argentina, Uruguay, southern Brazil, and central-southern Paraguay, where a large part of the population and the economic activities of the continent are located. Most of the SSA belongs to the La Plata basin (LPB), the second-largest basin in South America, with economic and ecological significance, as well as increasing demands as a water resource and a source of hydropower (Barros et al. 2006). Pampas, one of the world's richest grasslands in terms of size and biodiversity, and a major agricultural resource, is also located in LPB (Viglizzo and Frank 2006). The SSA is affected by the South American monsoon system (Nogués-Paegle et al. 2002), and both continental and ocean surface conditions (Pacific, Indian, and Atlantic Oceans) may affect precipitation over the SSA (e.g., Drumond et al. 2008; Sörensson and Menéndez 2011; Cherchi et al. 2014; Nieto et al. 2014). Droughts are a recurrent phenomenon in areas of the SSA, with impacts including the reduction of crop yields, streamflow deficiencies, and consequent problems for hydropower generation (Carbone et al. 2004; Rivera and Penalba 2014).

The specific analyses covered in this catalog for each RR are a) major climatological moisture sources and sinks, b) the climatic annual cycle of the moisture uptake over the sources, and of the moisture supply from the source into the RR (and from the RR into its climatological sink), c) drought episodes at three 
time scales (SPEI-1, -6, and -12) during the period 1980-2015, d) anomalies of these components of the Lagrangian approach for the most severe meteorological drought episode registered during the period analyzed (identified through SPEI-1), and e) the linear correlation between the results from the Lagrangian analysis and the SPEI-1 time series during 1980-2015.

METHOD. Lagrangian approach for analysis of moisture transport. The investigation of moisture transport in this study is based on the method developed by Stohl and James $(2004,2005)$, which made use of the Lagrangian flexible particle dispersion model (FLEXPART; Stohl et al. 2005). In the FLEXPART model, the atmosphere is divided homogeneously into 3D finite elements (hereafter "particles") that are advected using three-dimensional wind data and superimposed stochastic turbulent and convective motions. The model utilizes a set of parameterizations. For example, the random motions in the planetary boundary layer (PBL) are calculated based on the Langevin equations. The height of the PBL is determined using a combination of the Richardson number and the lifting parcel technique. The parameterization of convective transport follows Forster et al. (2007). Although low-resolution datasets cannot resolve individual convective cells, the large-scale effects of convection can be reproduced. More technical details concerning FLEXPART are discussed by Stohl et al. (2005).

The particle positions (latitude, longitude, and altitude) and specific humidity ${ }^{3}(q)$ are recorded every $6 \mathrm{~h}$. The change in the specific moisture of each particle (of mass $m$ ) along its trajectory is proportional to the freshwater flux in the particle (the difference between the evaporation $e$ and precipitation $p, e-p$ ) and can be expressed as $e-p=m d q / d t$. By summing $(e-p)$ for all the particles residing in the atmospheric column over a given area, the freshwater flux connected with the tracked particles $(E-P)$ is obtained, where $E$ and $P$ are the evaporation and precipitation rate per unit area, respectively. In other words, $(E-P)$ in a grid point is the sum of the values of $(e-p)$ for all tracked particles crossing the overlying atmospheric column. A complete review of this method, and its advantages and disadvantages with respect to other approaches for moisture transport analysis, is presented in Gimeno et al. (2012).

The FLEXPART V9.0 particle dispersion model was fed with the ERA-Interim global reanalysis dataset from the European Centre for Medium-Range Weather Forecasts (ECMWF; Dee et al. 2011), with a horizontal resolution of $1^{\circ}$ on 61 vertical levels, ranging from 1,000 to $0.1 \mathrm{hPa}$. Since FLEXPART requires high-quality data for wind and humidity, the ERA-Interim reanalysis data are the most appropriate to feed the model (Gimeno et al. 2013) because they reproduce the hydrological cycle in a more realistic way than the ERA-40 data and other reanalysis products, such as the Modern-Era Retrospective Analysis for Research and Applications (MERRA) and Climate Forecast System Reanalysis (CFSR) (Trenberth et al. 2011; Lorenz and Kunstmann 2012) data.

The analysis covered the period from 1980 to 2015. Because the FLEXPART model requires high-quality data for wind and humidity, the restriction of using reanalysis data post-1979 is justified by the inclusion of satellite information, which contributed to minimize the errors in both variables (Gimeno et al. 2013). For this work, the outputs of FLEXPART came from a global simulation in which the atmosphere was divided into approximately 2 million particles. The frequency of trajectory generation is once a day, at 0600 UTC, and the changes in specific moisture were computed every $6 \mathrm{~h}(0000,0600,1200$, and 1800 UTC). The particles were tracked for a period of 10 days, which is the global average residence time of water vapor ${ }^{4}$ in the atmosphere (Trenberth 1998; Numaguti 1999). The analysis of the $E-P$ field averaged over the 10-day period reveals the main sources and sinks of moisture for a given region. According to Stohl and James (2004), moisture sources are those regions where the resulting moisture budget of the backward in time tracked particles favors evaporation, that is, areas where $(E-P)>0$. The air masses take up moisture over these regions along their trajectories toward the target area. The forward-tracking analysis identifies those points at which the moisture budget of the air particles shows a supply of moisture to the atmosphere along trajectories from a given region, that is, the region's moisture sinks (areas where precipitation exceeded evaporation, $E-P<0$ ). In addition, a forward analysis may be conducted from the sources to estimate their moisture supply (negative values of $E-P$ ) for a target region. To be consistent with the resolution of the ERA-Interim data, the outputs from the Lagrangian approach were rearranged in a $1^{\circ}$ horizontal resolution grid. All the remaining fields analyzed in this work were also interpolated to a $1^{\circ}$ resolution (where they were originally available

\footnotetext{
${ }^{3}$ Specific humidity is mass of water vapor in a unit mass of moist air.

${ }^{4}$ Residence time of water vapor measures how much time the water molecule spends in the atmosphere.
} 
in a different resolution) before proceeding with the calculations.

Drought identification and analysis. Given the difficulties in quantification, several indices have been developed to identify drought and to establish its severity (Heim 2002; Mishra and Singh 2010; Mukherjee et al. 2018). The World Meteorological Organization (WMO) recommends the use of the standardized precipitation index (SPI) for operative monitoring purposes (Hayes et al. 2011), a standard methodology to calculate this index already exists (WMO 2012). The main advantage of this index is the ability to calculate it on different time scales, which is essential when adapting the different response times of usable water sources to precipitation variability (McKee et al. 1993), with implications for the accurate identification of hydrological, agricultural, and environmental impacts (Lorenzo-Lacruz et al. 2013; Vicente-Serrano et al. 2013; Peña-Gallardo et al. 2018). The main problem with the SPI is that calculation is exclusively based on precipitation, but other meteorological variables also affect drought occurrence and severity. Among these variables, the atmospheric evaporative demand (AED) ${ }^{5}$ is essential to determine drought severity and intensification processes, which is stressed in recent "flash drought" episodes in which drought has evolved in few weeks as a consequence of a strong AED (Otkin et al. 2017).

For this reason, in this study, drought severity is identified by the SPEI (Vicente-Serrano et al. 2010). The SPEI follows the same conceptual approach as the SPI, being calculated at various time scales, but also includes the AED in calculations by means of a simple climatic balance (precipitation minus AED). The SPEI is equally sensitive to precipitation and the AED (Vicente-Serrano et al. 2015) and is advantageous in relation to other indices which can identify drought severity and impacts worldwide (e.g., Vicente-Serrano et al. 2012). Details of the SPEI calculation can be found in Vicente-Serrano et al. (2010), Beguería et al. (2014), and Vicente-Serrano and Beguería (2016).

Following the method applied by Drumond et al. (2017) and Stojanovic et al. (2018b), 1-, 6-, and 12-month SPEI time scales for 1980-2015 were calculated for each RR through time series of monthly precipitation (PRE) and AED, averaged over the region, in order to identify the domain-scale episodes at different time scales. The data come from the Climatic Research Unit (CRU) Time Series (TS)

${ }^{5}$ Atmospheric evaporative demand is the upper limit of the atmospheric demand for water from a natural surface. version 3.24.01 (Harris et al. 2014), available with a horizontal resolution of $0.5^{\circ}$. The main strength of the CRU dataset is that it compiles station data of multiple variables from numerous data sources into a consistent format, providing high spatial resolution and long time series, which is useful for multidecadal analysis (NCAR 2018). Recent studies around the world (e.g., Bless et al. 2018; Zhao et al. 2018; Kannenberg et al. 2018; Zambreski et al. 2018; Liu et al. 2018) made use of this data. A modified version of the Penman-Monteith reference evapotranspiration (ETo) equation is used in the CRU dataset as a metric of the AED. This ETo is a form of AED since resistance factors are not temporally and spatially variable and only depend on the four main meteorological drivers of AED (i.e., air temperature, radiation, atmospheric humidity, and wind speed, as is the case for FAO-56 crop reference evaporation; Allen et al. 1998). Although the use of temperature and precipitation from the ERA-Interim would be consistent with the results from the Lagrangian analysis, the good quality of precipitation data from CRU (Sun et al. 2018) provides a more accurate identification of the drought episodes.

The identification of the domain-scale drought episodes during 1980-2015 follows the criteria of McKee et al. (1993), in which an episode starts when the SPEI value first falls below zero (month included), followed by a value of -1 or less, and ends when the SPEI returns to a positive value (month not included). Some variables for the different drought episodes were then computed: severity, duration, intensity, and peak value (Spinoni et al. 2014; Tan et al. 2015). The severity represents the absolute sum of all SPEI values during the episode, duration signifies the number of months between the first and last month of the episode, intensity is calculated as the ratio between the severity and duration, and the peak value is the most negative value registered during the event.

UNCERTAINTIES. Concerning the accuracy of CRU data, Dai and Zhao (2017) pointed out the limitations of an older version (TS3.10.01) due to the poor coverage of data from the 1990s. Although the accuracy of the dataset at a particular grid point is dependent on the number of surrounding weather stations available for the interpolation (Onyutha 2018), the computations shown here are based on time series averaged in a large-scale spatial domain, which may minimize the errors in some regions due to the poor data coverage. In addition, the CRU TS 3.24.01 dataset was chosen for this study because it provides both precipitation and temperature, fields necessary 
a) $\quad 3$ PRE $=\mathrm{AED}$
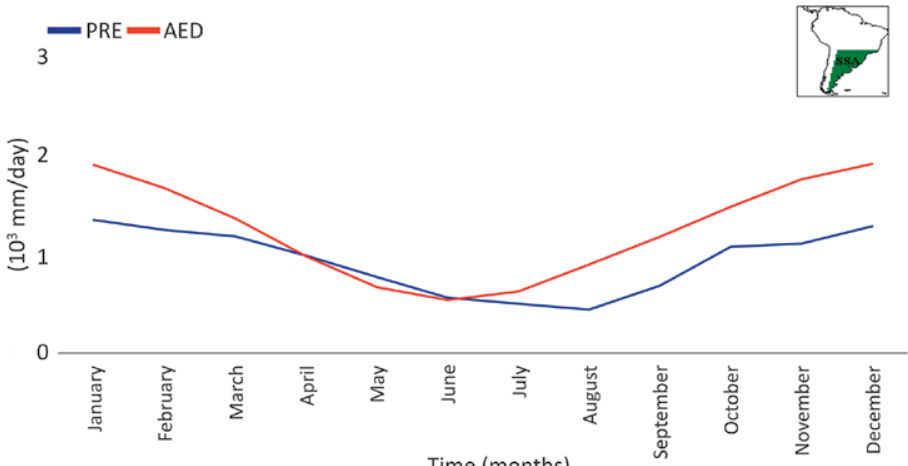

b)

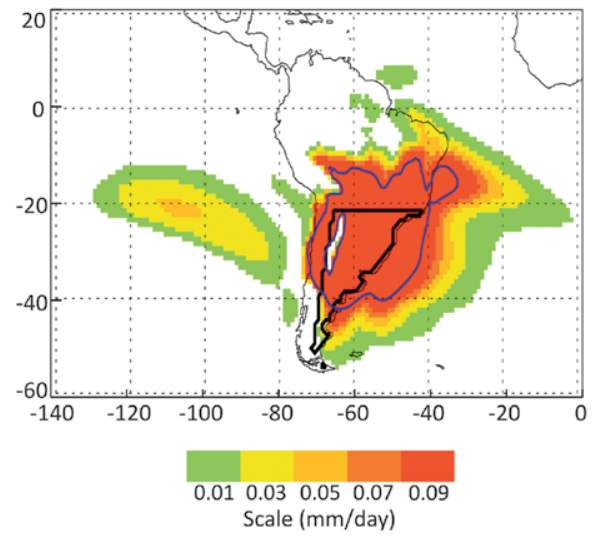

d)
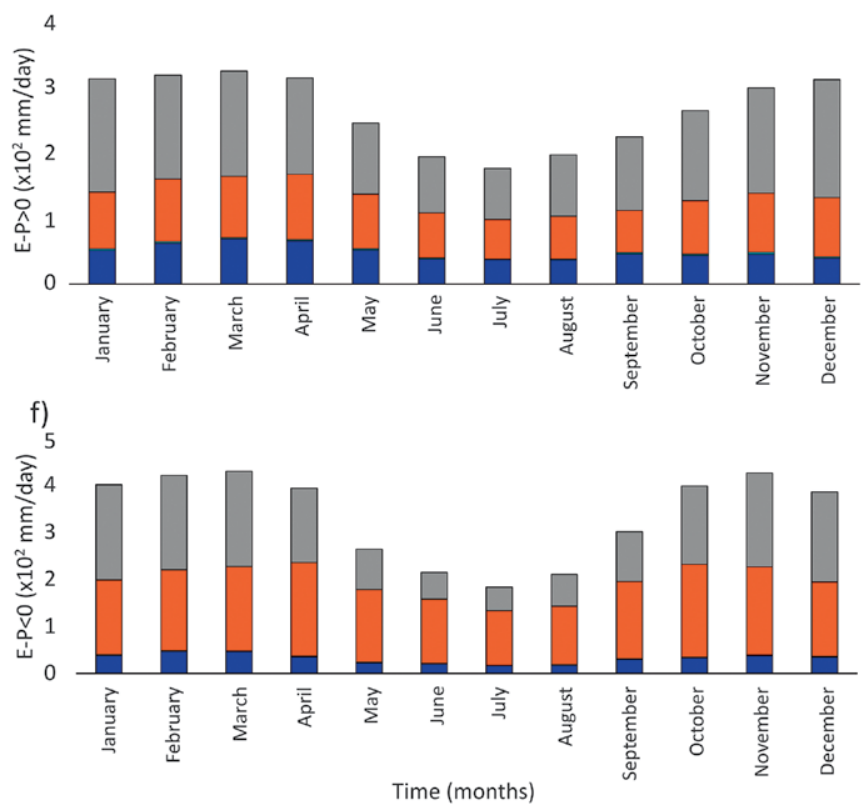

c)

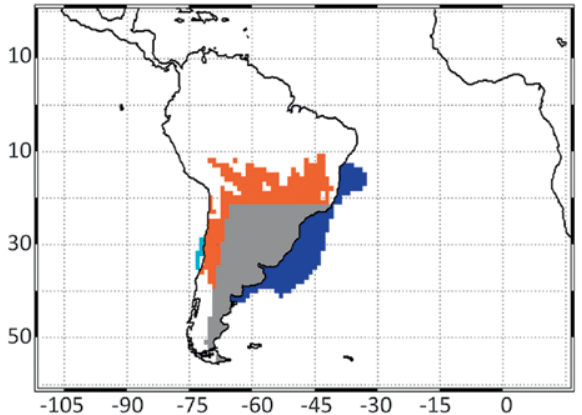

$\square$ SAT $\square$ SPO —TER $\square$ SSA

e)

g)
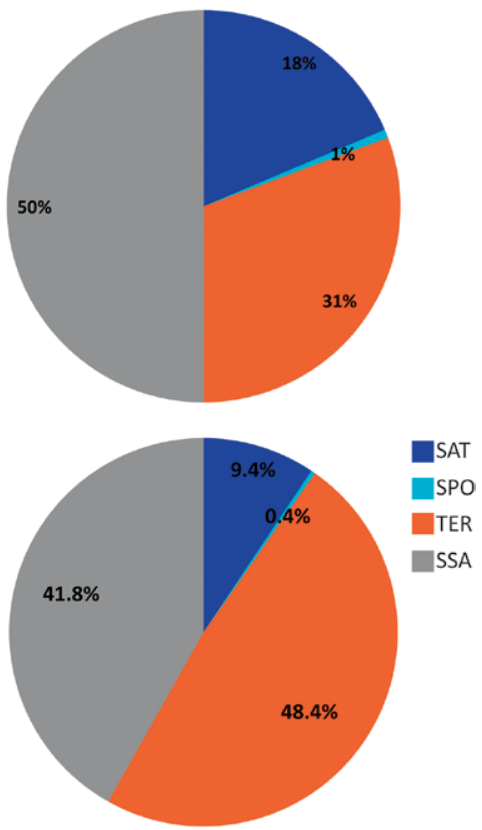

FIG. 2. (a) The annual climatological precipitation cycle (PRE, blue line) and atmospheric evaporative demand (AED, red line) integrated over the SSA RR for 1980-2015. The SSA region is shown in dark green. Data are from the CRU TS 3.24.0I. (b) The positive values of the annual climatological $(E-P)$ integrated backward in time over $I 0$ days for the SSA RR ( $\left.\mathrm{mm} \mathrm{day}^{-1}\right)$. The blue line delimits the moisture source areas selected using the 95th percentile of the $(E-P)>0$ values (i.e., $0.15 \mathrm{~mm}^{-1 a y}{ }^{-1}$ ). (c) Schematic representation of the main moisture sources for the SSA RR between 1980 and 2015: SPO, SAT, TER, and the region itself (SSA-AR5). (d) The annual climatological cycle of the moisture uptake $(E-P>0)$ integrated over the sources obtained from backward analysis for the SSA RR, and (e) the respective contribution of each source toward the total annual value. (f),(g) As in (d) and (e), but for moisture supply $(E-P<0)$ from the sources into the SSA RR, estimated through the forward analysis. Scale in mm day ${ }^{-1}$. 
for the computation of the SPEI, thus reducing errors due to the mixing of different datasets.

According to Stohl and James (2004), the Lagrangian method is not able to calculate $E$ and $P$ separately. This approach is also limited by the use of the time derivative of moisture, in which unrealistic fluctuations can be interpreted as moisture fluxes, as well as by the limited resolution and uncertainties of the input data. Partly, such noise compensates among the many particles in an atmospheric column over area $A$, such that the problem is less pronounced for instantaneous $E-P$ values. For this analysis, net evaporation $(E-P>0)$ or the net precipitation $(E-P<0)$ values were discounted after calculated the monthly $(E-P)$ mean fields, in agreement with the study of Castillo et al. (2014). Using the same approach applied here, they analyzed the impact of discounting the $(E-P)>0$ term at different temporal scales from the climatological estimate of the surface freshwater flux, and their results show that the net evaporation can be discounted after $E-P$ has been integrated without altering the general patterns of net precipitation, if $E-P>0$ is discounted using a monthly or longer time scale.

The regions actuating as major moisture sources were identified from the climatological annual means of $E-P$, following previous works such as Drumond et al. (2014) and Sorí et al. (2017). This field summarizes the most relevant moisture sources throughout the year. Such moisture sources are not stationary (Gimeno et al. 2013), and although defining them at a monthly scale would be more realistic, a comparative analysis of the evolution of its contribution throughout the year would not be possible when considering the monthly variation of spatial domain of the sources.

Another issue would be the residence time. While the 10-day period of tracking is somewhat arbitrary, it reflects the average residence time of water vapor in the global atmosphere (Trenberth 1998; Numaguti 1999). As pointed out by Drumond et al. (2017), the estimate of the residence time is still a controversial issue, being dependent on the methodologies applied. Although the residence time can vary both spatially and seasonally, this study considers the global 10-day residence time applied by Stohl and James (2004, 2005) in order to apply the same value for all the regions investigated here and to be consistent with most previous studies applying the same methodology around the world (e.g., Drumond et al. 2008, 2014, 2016, 2017; Gimeno et al. 2010, 2013; GómezHernández et al. 2013; Nieto et al. 2014; Salah et al. 2018; Sorí et al. 2017; Stojanovic et al. 2018a).
SPEI was computed from time series averaged over the RR domain in order to identify the domain-scale episodes affecting each region, following the method applied in Drumond et al. (2017) and Stojanovic et al. (2018b). However, because each drought event is unique in terms of its temporal and spatial development, a gridpoint analysis would reveal areas more affected by dry conditions during a particular episode.

DESCRIPTION OF THE CATALOG. Item I: Climatological annual cycle of precipitation and atmospheric evaporative demand over the RR. The 1980-2015 monthly averages of the PRE and AED integrated over the RR illustrate the climatological annual cycle of both fields necessary for the computation of the SPEI. Figure 2a shows an example for the SSA region.

Item 2: Climatological annual cycle of the Lagrangian analysis components for the $R R$. In the moisture source analysis, the major moisture sources have been identified through the climatological annual means of $E-P$ obtained from the tracking of air masses over a given target region (for this study, the RRs) backward through time. The daily $E-P$ values associated with the set of backward trajectories from a given RR are accumulated along the tracks during the 10-day analysis period. The percentile criterion was applied for each one of the RR to define the respective threshold delimiting the spatial extent of the major sources and sinks of moisture. The 95th percentile of the positive part of $E-P$ obtained from the respective RR global climatology on the annual scale returns the grid points in which $5 \%$ of the highest positive $(E-P)$ values are found. These areas showing the highest 10-day accumulated $(E-P)>0$ values from the backward tracking are the major moisture sources according to the methodology applied here. They indicate those regions where the air masses take up a large amount of moisture on their path to the RR, summarizing the most relevant moisture sources throughout the year. The opposite criterion is valid for defining the major moisture sinks. Keeping the spatial domain of a source stationary allows following the annual cycle of its contribution, as well as its variations during a drought episode. The use of percentiles instead of absolute values is useful to establish a criterion valid both for different regions and sensitive to their respective $E-P$ values. This criterion was successfully applied in previous studies for areas characterized by different climatic conditions, such as tropics (Drumond et al. 2014; Sorí et al. 2017), European and Mediterranean regions (Stojanovic et al. 2018a), the 
Fertile Crescent (Salah et al. 2018), and even polar regions (Vázquez et al. 2016).

For the example given here, the main moisture sources for the SSA RR, according to the threshold of $0.15 \mathrm{~mm} \mathrm{day}^{-1}$ (95th percentile of $E-P>0$ values obtained for the global map of the annual climatological $E-P$ for the backward experiment from SSA, indicated as a blue contour line in Fig. 2b), are displayed in Fig. 2c. According to the analysis, there are three remote major moisture sources for the SSA RR (gray region in Fig. 2c), namely, the South Atlantic Ocean (SAT, dark blue), the South Pacific Ocean (SPO, light blue), and a terrestrial source (TER, orange). For consistency between figures for different RRs, the remote terrestrial sources are given in orange and the RR itself appears in gray.

The annual climatological cycle of the Lagrangian analysis results associated with each $\mathrm{RR}$ is displayed in this item. The moisture uptake $(E-P>0$, backward run from the RR) integrated over the sources is shown in the Figs. $2 \mathrm{~d}$ and $2 \mathrm{e}$ for the SSA RR, illustrating the moisture source analysis. In the moisture supply analysis, the forward tracking analysis starts from the air masses located over each one of the $95 \%$ moisture source regions defined according to the moisture source analysis. The $E-P$ values were then calculated along the airmasses trajectories forward in time during 10 days, and the negative values of $(E-P)$ accumulated during this period over the $\mathrm{RR}$ (the target region) estimate the moisture supply from the source into the $\mathrm{RR}(E-P<0$, forward run). Figures $2 \mathrm{f}$ and $2 \mathrm{~g}$ display the moisture supply results for the SSA RR. The 1980-2015 monthly averages for the sources analyzed are superposed on a histogram, and the annual values in percentage terms are summarized in a pie chart.

Analyzing the SSA RR as an example (Fig. 2) of the interpretation of the results, the moisture uptake over the sources (Figs. 2d,e) and the moisture supply from each source into SSA (Figs. 2f,g) show a similar annual pattern, with minimum values during JuneAugust (austral winter), reaching a maximum during November-March (austral summer). The moisture uptake by particles traveling toward the SSA RR prevails over the SSA itself and TER regions (Figs. 2d,e). The annual cycle of moisture supply from the sources into the SSA (the moisture from these sources left over the SSA RR by particles) shows that the terrestrial supply (TER) prevailed throughout the year, even when reduced in the austral winter months (Fig. 2f).

On one hand, the moisture supplied by the SAT into the SSA RR is minimal in comparison with other sources, suggesting that this source is not as effective in generating precipitation over the SSA RR when compared to the SSA RR and TER. On the other hand, the moisture transport from the TER source is more relevant for the SSA RR, seen in the increase in the relative importance of moisture uptake over the source and, mainly, through the predominance of the supply of moisture from the TER in the annual cycle.

The importance of the RR as a source of moisture for remote continental areas has also been investigated in the moisture sink analysis. The identification of remote moisture sinks is based on the tracking of air masses over the RR forward in time and on the posterior integration of the $E-P$ daily values along the 10-day trajectories. The 99th percentile of the negative values of $E-P$ (areas where precipitation exceeded evaporation), obtained from the global climate on an annual scale, defined the spatial extent of these major sinks, and indicates regions where the air masses lose a large amount of moisture on their path from the RR. In the forward analysis, the air mass is originally over the $\mathrm{RR}$, but the moisture existing on it may not necessarily be evaporated from the RR, and air masses may take up moisture from additional evaporation sources along the way toward its sink. For the SSA RR, the main continental moisture sink, according to the threshold of $-0.34 \mathrm{~mm} \mathrm{day}^{-1}$ (99th percentile of $E-P<0$ values obtained for the global map of the $E-P$ for the forward experiment from SSA, indicated as a red contour line in Fig. 3a), constitutes a small portion west of the RR (TER, orange region in Fig. 3b).

To illustrate how the moisture transport from the RR may affect remote continental precipitation, the annual cycle of PRE over its sink is plotted together with the moisture supply $(E-P<0$ from the forward run) from the RR to its sink (Fig. $3 c$ for the SSA RR). All values are the total over an area. Figure $3 \mathrm{c}$ exemplifies the results for the SSA RR, and the 1980-2015 annual cycle reveals that the supply from SSA into its sink (gray line) and the PRE over its sink (PRE, blue line) follow a similar evolution, with a maximum during the austral summer, and a minimum during the austral winter months, which suggests that the RR significantly influences precipitation regime of its moisture sink.

\section{Item 3: SPEI time series and drought episodes identi-} fied over the RR at different scales during 1980-2015. The time series of the SPEI on the scale of 1,6 , and 12 months over the RR are plotted to show the evolution of the index on different time scales (conditions accumulated over monthly, semiannual, and annual periods, respectively). Figure 4 shows the time series 
a)

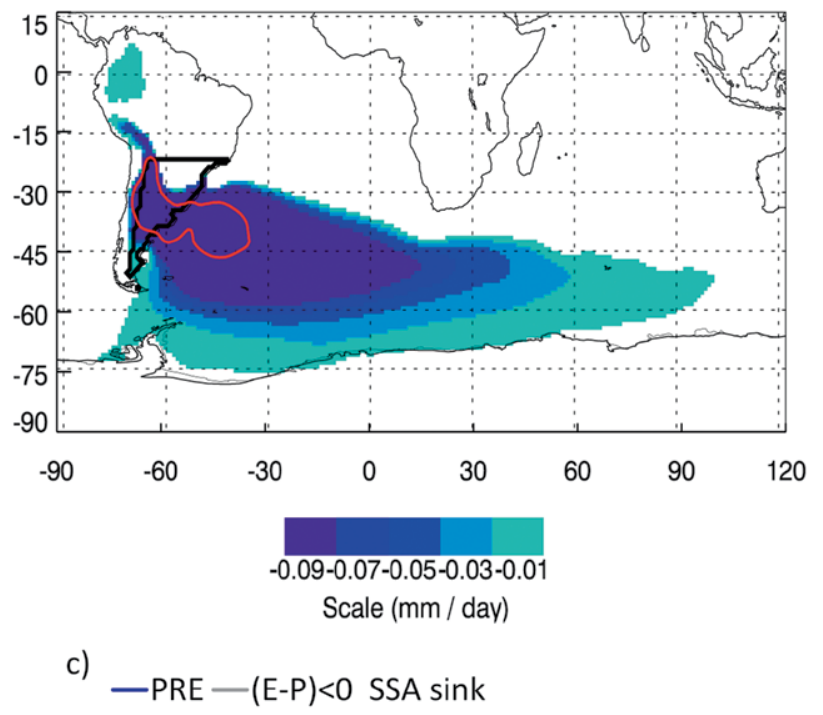

b)

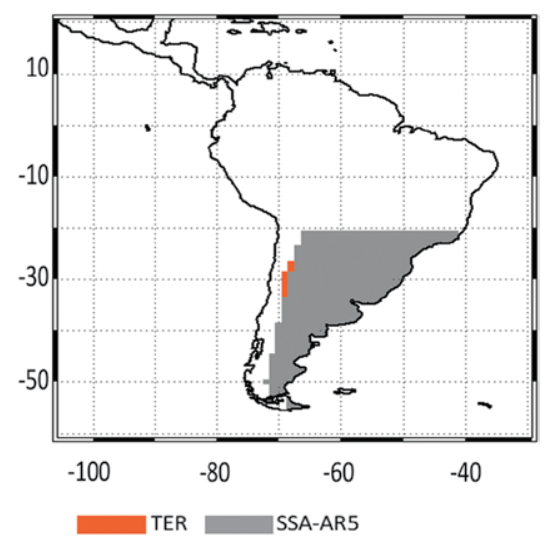

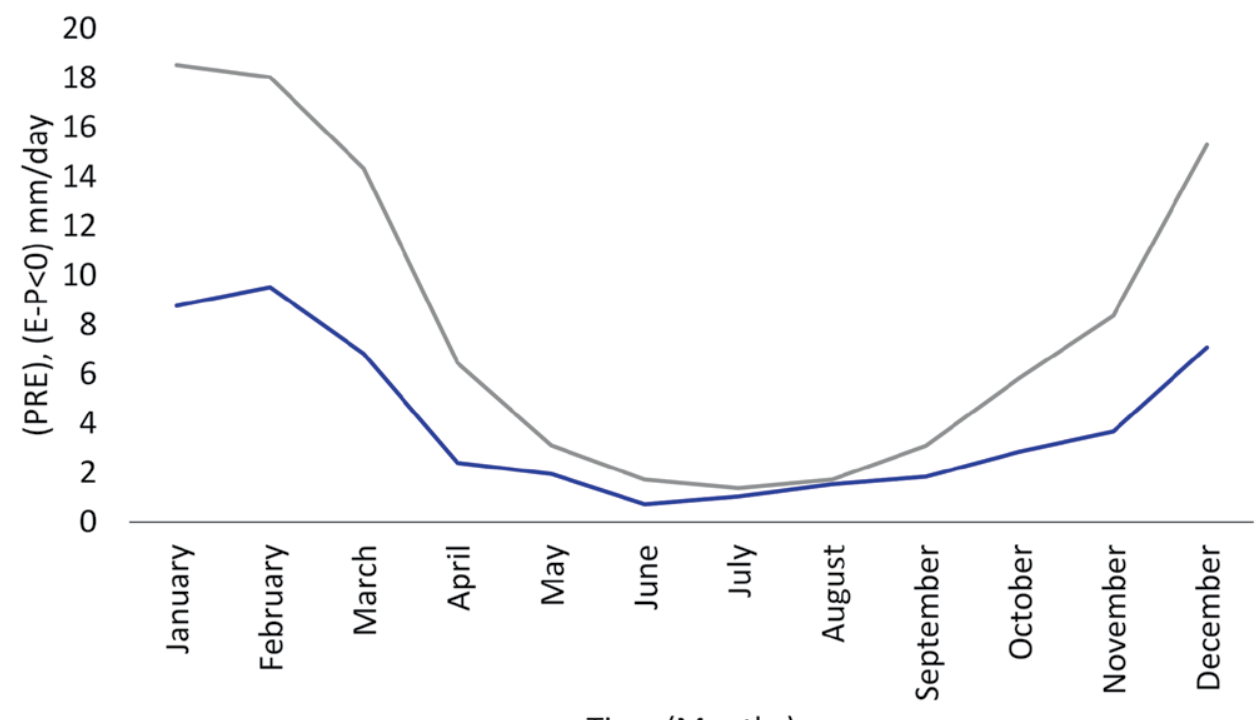

Time (Months)

Fig. 3. (a) Annual climatological $(E-P<0)$ values integrated forward in time over 10 days from the SSA RR $\left(\mathrm{mm}\right.$ day $\left.^{-1}\right)$. The red line delimits the moisture sink areas selected using the 99 th percentile of the $(E-P)<0$ values (i.e., $-0.34 \mathrm{~mm} \mathrm{day}^{-1}$ ). (b) Schematic representation of the remote terrestrial moisture sink (TER, orange) for the SSA RR. (c) The annual climatological cycle of precipitation (blue line) and moisture supply (gray line) integrated over the SSA moisture sinks. Scale in $\mathbf{m m ~ d a y}{ }^{-1}$.

of the SPEI over the SSA RR, with positive values in blue indicating wet periods, and negative values in red showing dry conditions.

A figure illustrating the drought episodes at domain-scale identified according to the criteria proposed by McKee et al. (1993) in each RR over the three time scales between 1980-2015 is included on the web page (Fig. 5 provides an example for the SSA RR), together with a list of the episodes and their respective indicators (Table 1 shows the SSA RR drought episodes at SPEI-1, SPEI-6, and SPEI-12 time scales).
Item 4: Anomalies of the Lagrangian analysis components for the most severe meteorological drought episode over the RR during 1980-2015. Precipitation deficit over an area may be related to changes in moisture transport, which can lead to drought (Drumond et al. 2016, 2017; Liu et al. 2017; Salah et al. 2018; Sorí et al. 2017; Stojanovic et al. 2018a,b). Thus, it is important to analyze how a meteorological drought episode may be associated with changes in the moisture transport. For this purpose, a case study regarding the anomalies of the Lagrangian analysis components during the most severe meteorological drought episode identified for 

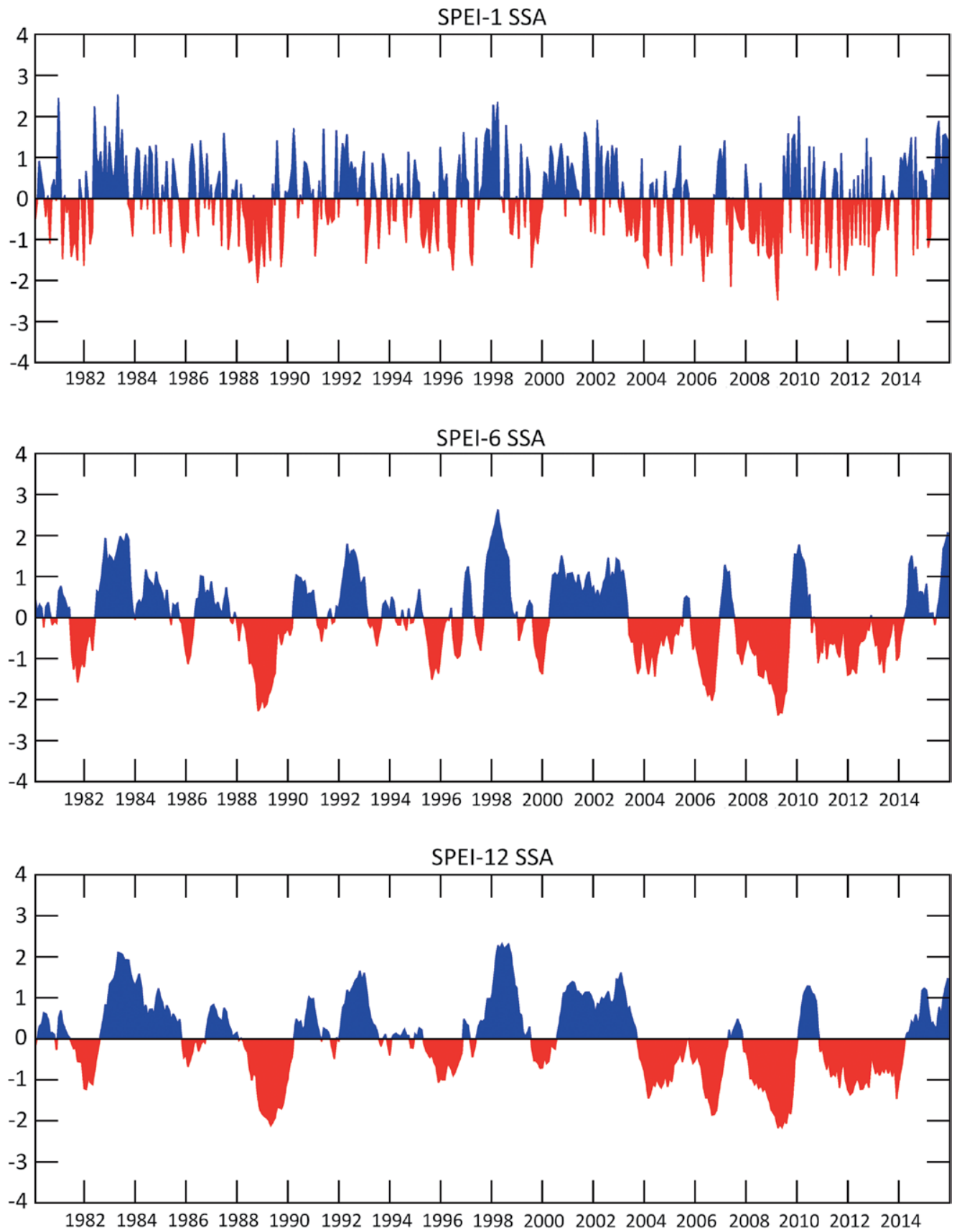

FIG. 4. Time series of SPEI-I, SPEI-6, and SPEI-12 for the SSA RR during 1980-2015. Data are from CRU TS 3.24.0I. Drought episodes over SSA during 1980-2015

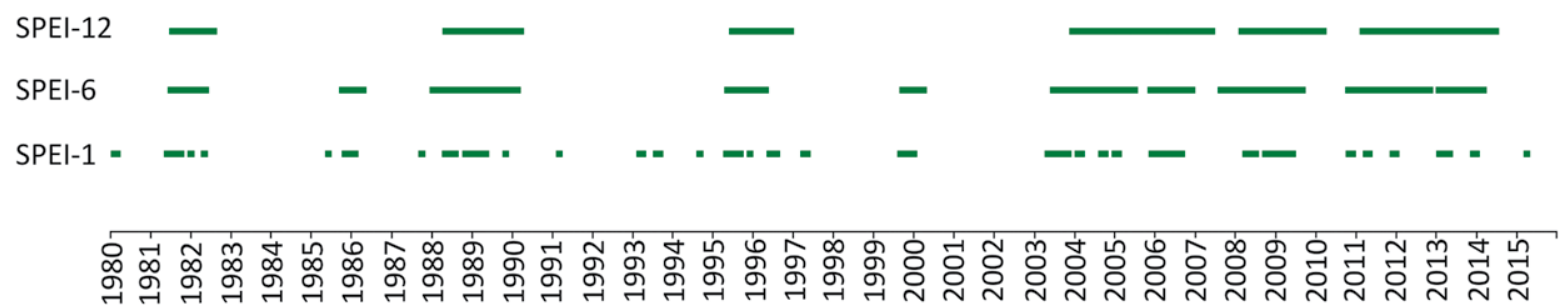

FIG. 5. SPEI-I, SPEI-6, and SPEI-I2 drought episodes that occurred over the SSA RR during 1980-20I5. The episodes were identified following the criteria of McKee et al. (1993). 


\begin{tabular}{|c|c|c|c|c|c|c|c|c|c|c|c|}
\hline 员 & 产 罗 & 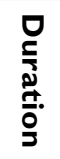 & 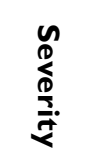 & 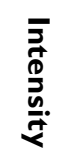 & $\begin{array}{l}\text { D } \\
\frac{\mathbb{N}}{\lambda}\end{array}$ & 号 & 产 & 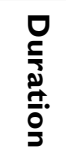 & 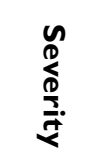 & 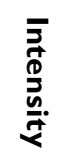 & $\begin{array}{l}\text { D } \\
\frac{\mathbb{D}}{\lambda}\end{array}$ \\
\hline \multicolumn{6}{|c|}{ SPEI-I } & \multicolumn{6}{|c|}{ SPEI-6 } \\
\hline Jan 1980 & Mar 1980 & 3 & 2.26 & 0.75 & -1.61 & Jul |98। & Jun 1982 & 12 & 10.78 & 0.90 & -1.58 \\
\hline Sep 1980 & Sep 1980 & I & 1.10 & 1.10 & -1.10 & Oct 1985 & May 1986 & 8 & 4.12 & 0.51 & -1.13 \\
\hline Mar 198I & Mar 198I & I & 1.48 & 1.48 & -1.48 & Jan 1988 & Mar 1990 & 27 & 27.22 & 1.01 & -2.28 \\
\hline May I98I & Oct 198I & 6 & 5.51 & 0.92 & -1.51 & May 1995 & May 1996 & 13 & 8.97 & 0.69 & -1.51 \\
\hline Dec 1981 & Jan 1982 & 2 & 1.67 & 0.83 & -1.64 & Sep 1999 & Apr 2000 & 8 & 6.48 & 0.81 & -1.38 \\
\hline Apr 1982 & May 1982 & 2 & 1.90 & 0.95 & -1.12 & Jun 2003 & Jul 2005 & 26 & 18.90 & 0.73 & -1.43 \\
\hline May 1985 & Jun 1985 & 2 & 1.54 & 0.77 & -1.18 & Nov 2005 & Dec 2006 & 14 & 17.25 & 1.23 & -2.03 \\
\hline Oct 1985 & Feb 1986 & 5 & 3.75 & 0.75 & -1.34 & Aug 2007 & Sep 2009 & 26 & 33.63 & 1.29 & -2.38 \\
\hline Jun 1987 & Jun 1987 & I & 1.17 & 1.17 & -1.17 & Oct 2010 & Nov 2012 & 26 & 19.89 & 0.76 & -1.40 \\
\hline Sep 1987 & Oct 1987 & 2 & 2.08 & 1.04 & -1.25 & Jan 2013 & Mar 2014 & 15 & 9.78 & 0.65 & -1.35 \\
\hline Feb 1988 & Feb 1988 & I & 1.17 & 1.17 & -1.17 & \multicolumn{6}{|c|}{ SPEI-12 } \\
\hline Apr 1988 & Aug 1988 & 5 & 5.03 & 1.01 & -1.54 & Jul I98I & Aug 1982 & 14 & 9.10 & 0.65 & -1.23 \\
\hline Oct 1988 & May 1989 & 8 & 9.67 & 1.21 & -2.05 & Apr 1988 & Mar 1990 & 24 & 30.81 & 1.28 & -2.11 \\
\hline Oct 1989 & Nov 1989 & 2 & 2.58 & 1.29 & -1.68 & May 1995 & Nov 1996 & 19 & 12.02 & 0.63 & -1.06 \\
\hline Feb I99| & Mar 1991 & 2 & 2.07 & 1.04 & -1.41 & Oct 2003 & Apr 2007 & 43 & 37.45 & 0.87 & -1.85 \\
\hline Feb 1993 & Apr 1993 & 3 & 2.90 & 0.97 & -1.59 & Dec 2007 & Jan 2010 & 26 & 34.51 & 1.33 & -2.17 \\
\hline Jul 1993 & Sep 1993 & 3 & 1.49 & 0.50 & -1.23 & Dec 2010 & Apr 2014 & $4 I$ & 34.66 & 0.85 & -1.47 \\
\hline Aug 1994 & Sep 1994 & 2 & 1.62 & 0.81 & -1.08 & \multirow{21}{*}{\multicolumn{6}{|c|}{$\begin{array}{l}\text { each RR at domain scale during } 1980-2015 \text { were } \\
\text { analyzed. } \\
\text { The SPEI-1 time scale, which corresponds to } \\
\text { the climatic water balance for one month, was } \\
\text { chosen to select the episodes because it is closely } \\
\text { related to meteorological droughts (Liu et al. } \\
\text { 2017). The most severe SPEI-1 episode selected } \\
\text { for each RR is taken from the list provided in } \\
\text { item 3. For the SSA RR, the selected domain- } \\
\text { scale episode was from September } 2008 \text { to June } \\
2009 \text {, with a } 10 \text {-month-long duration, a sever- } \\
\text { ity of } 11.75 \text {, an intensity of } 1.18 \text {, and a peak of } \\
-2.48 \text {. Previous studies state that the drought of } \\
\text { 2008/09 in the SSA RR, accompanied by warmer } \\
\text { temperatures and inhibited precipitation over the } \\
\text { region, was among the most significant in terms } \\
\text { of both intensity and extent, causing significant } \\
\text { economic losses due to a reduction in crop yields } \\
\text { and water supply deficiencies (Marengo et al. }\end{array}$}} \\
\hline Apr 1995 & Sep 1995 & 6 & 5.54 & 0.92 & -1.33 & & & & & & \\
\hline Nov 1995 & Dec 1995 & 2 & 2.19 & 1.09 & -1.29 & & & & & & \\
\hline May 1996 & Aug 1996 & 4 & 4.80 & 1.20 & -1.75 & & & & & & \\
\hline Mar 1997 & May 1997 & 3 & 3.15 & 1.05 & -1.64 & & & & & & \\
\hline Aug 1999 & Jan 2000 & 6 & 5.37 & 0.89 & -1.69 & & & & & & \\
\hline Apr 2003 & Nov 2003 & 8 & 5.29 & 0.66 & -1.04 & & & & & & \\
\hline Jan 2004 & Mar 2004 & 3 & 4.59 & 1.53 & -1.71 & & & & & & \\
\hline Aug 2004 & Oct 2004 & 3 & 2.87 & 0.96 & -1.40 & & & & & & \\
\hline Dec 2004 & Feb 2005 & 3 & 2.43 & 0.81 & -1.65 & & & & & & \\
\hline Jul 2005 & Jul 2005 & I & 1.39 & 1.39 & -1.39 & & & & & & \\
\hline Nov 2005 & Sep 2006 & II & 11.20 & 1.02 & -2.04 & & & & & & \\
\hline Jun 2007 & Jun 2007 & I & 2.15 & 2.15 & -2.15 & & & & & & \\
\hline Mar 2008 & Jul 2008 & 5 & 5.12 & 1.02 & -1.40 & & & & & & \\
\hline Sep 2008 & Jun 2009 & 10 & 11.75 & 1.18 & -2.48 & & & & & & \\
\hline Jun 2010 & Jun 2010 & I & 1.40 & 1.40 & -1.40 & & & & & & \\
\hline Aug 2010 & Aug 2010 & I & 1.11 & 1.11 & -1.11 & & & & & & \\
\hline Oct 2010 & Dec 2010 & 3 & 3.43 & 1.14 & -1.75 & & & & & & \\
\hline Mar 20II & May 20II & 3 & 3.28 & 1.09 & -1.69 & & & & & & \\
\hline Sep 2011 & Sep 2011 & I & 1.88 & 1.88 & -1.88 & & & & & & \\
\hline Nov 2011 & Jan 2012 & 3 & 3.71 & 1.24 & -1.75 & & & & & & \\
\hline Mar 2012 & Mar 2012 & I & 1.15 & 1.15 & -1.15 & \multirow{6}{*}{\multicolumn{6}{|c|}{$\begin{array}{l}\text { 2009, 2010; Aceituno et al. 2009; Bidegain et al. } \\
\text { 2010; D'Ambrosio et al. 2013; Carbone et al. 2015, } \\
\text { Müller et al. 2014). This episode occurred dur- } \\
\text { ing a prolonged 2007-09 La Niña event, which } \\
\text { favored dry conditions over the region (e.g., Diaz } \\
\text { et al. 1998). }\end{array}$}} \\
\hline Jul 2012 & Jul 2012 & I & 1.13 & 1.13 & -1.13 & & & & & & \\
\hline Sep 2012 & Sep 2012 & I & 1.15 & 1.15 & -1.15 & & & & & & \\
\hline Nov 2012 & Nov 2012 & 1 & 1.18 & 1.18 & -1.18 & & & & & & \\
\hline Jan 2013 & May 2013 & 5 & 4.47 & 0.89 & -1.88 & & & & & & \\
\hline Nov 2013 & Jan 2014 & 3 & 2.01 & 0.67 & -1.90 & & & & & & \\
\hline Aug 2014 & Aug 2014 & I & 1.38 & 1.38 & -1.38 & \multirow{3}{*}{\multicolumn{6}{|c|}{$\begin{array}{l}\text { Monthly anomalies of the following fields for } \\
\text { the most severe meteorological drought episode } \\
\text { selected over each RR are plotted in a similar way, } \\
\text { shown in Fig. } 6 \text { for the SSA RR: }\end{array}$}} \\
\hline Oct 2014 & Oct 2014 & I & 1.23 & 1.23 & -1.23 & & & & & & \\
\hline Mar 2015 & Apr 2015 & 2 & 2.10 & 1.05 & -1.20 & & & & & & \\
\hline
\end{tabular}


a)

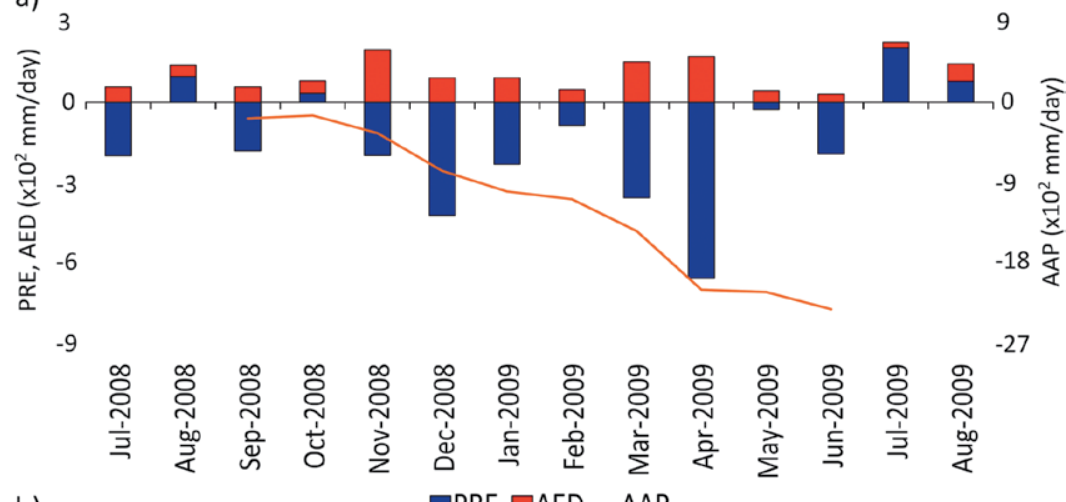

b)

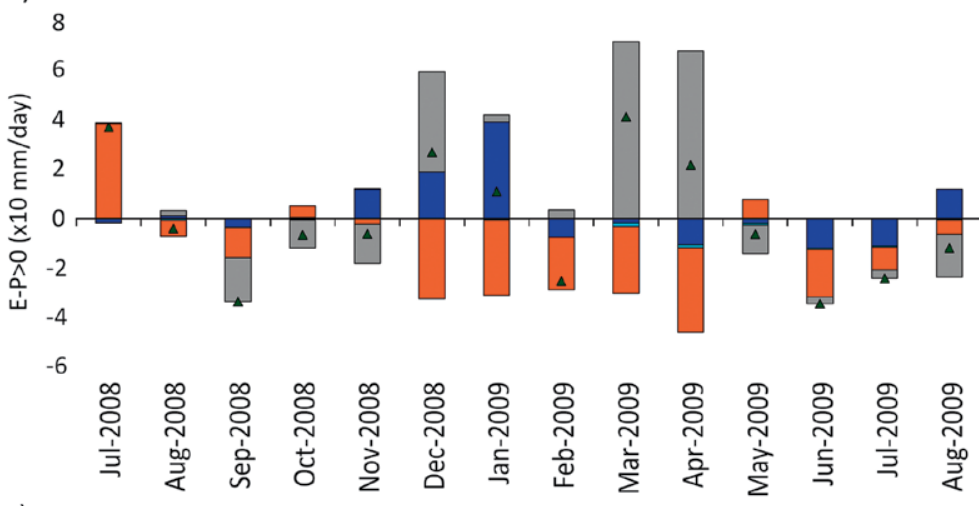

c) 1

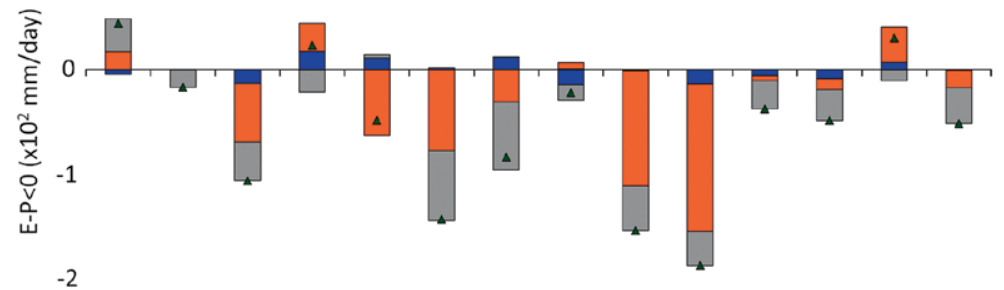

$-2$

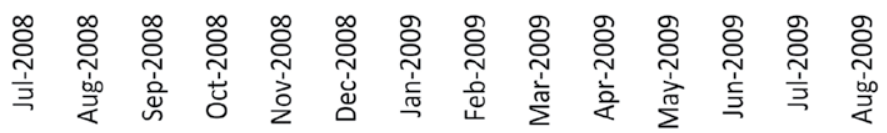

Drought episode

$\square$ SAT $\square$ SPO $\square$ TER $\square$ SSA $\triangle \mathrm{AA}$

d) 14

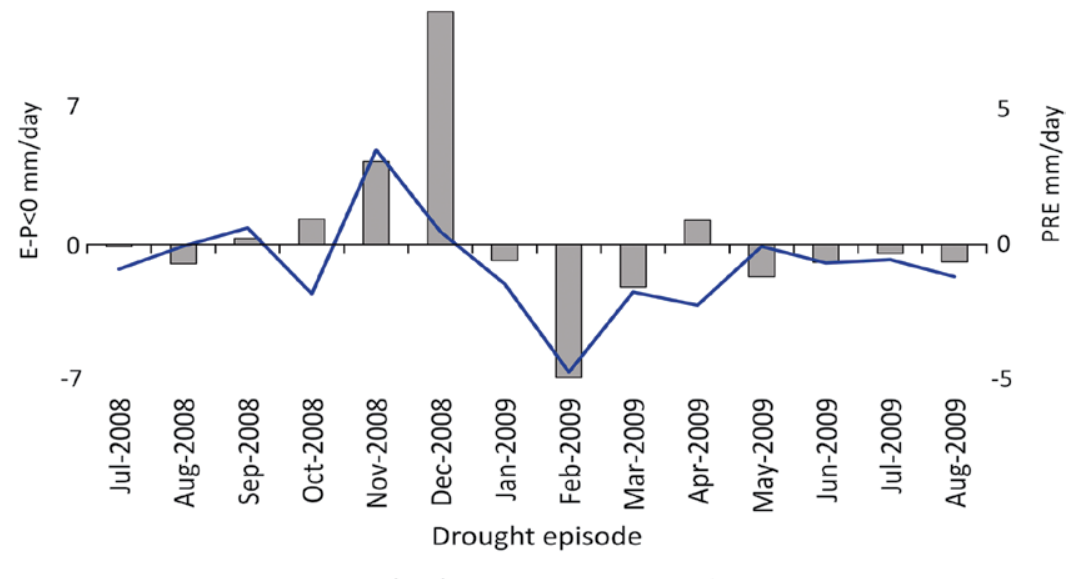

$\square(\mathrm{E}-\mathrm{P})<0 \quad-\mathrm{PRE}$ SSA sink
1) PRE and AED (blue and red bars, respectively, Fig. 6a) integrated over the RR, together with the precipitation anomalies accumulated during the episode (orange line, Fig. 6a) using the CRU dataset. The scale is in mm day ${ }^{-1}$.

2) Moisture uptake $(E-P>0)$ integrated over the sources, as well as the accumulated anomaly from all the sources (Fig. 6b). For this example, the bars show the anomalies over four different moisture sources [SAT (dark blue), SPO (light blue), terrestrial moisture sources surrounding the region (TER), and the region itself (SSA)]. For each month, the bars for each source region are superimposed to avoid cluttering. The height of each bar represents the magnitude of the anomalies from the respective source. For each month, a triangle indicates the total accumulated anomaly from all the sources. The values are obtained via the backwardin-time Lagrangian analysis from the RR, and the scale is in $\mathrm{mm}$ day ${ }^{-1}$.

FIG. 6. (a) Monthly anomalies of PRE, $A E D$, and accumulated precipitation anomalies (AAP; data from CRU TS 3.24.0I) during the most severe drought episode that occurred over the SSA RR. (b) As in (a), but for moisture uptake $(E-P>0)$ over the sources with the accumulated anomaly of the sources (AA). (c) As in (a), but for moisture supply $(E-P<0)$ from each source into the SSA RR with the accumulated anomaly of the supply from all of the sources (AA). (d) Monthly anomalies of the moisture supply from the SSA $\mathbf{R R}$ into its remote terrestrial sink and PRE over the sink accumulated during the drought episode. Scale in mm day ${ }^{-1}$. 
3) Moisture supply $(E-P<0)$ from each source into RR, and the accumulated anomaly of the supply from all the sources (Fig. 6c; values integrated over RR). The structure of the graphic also follows Fig. 6b. The values are obtained via the forward Lagrangian analysis from each source, and the scale is in $\mathrm{mm} \mathrm{day}^{-1}$.

4) Moisture supply $(E-P<0)$ from the $\mathrm{RR}$ into its climatic sink (identified in item 2), and the PRE over the sink (values integrated over the sink; Fig. 6d, bars and contour line for supply and PRE, respectively). The values of the supply are obtained via the forward Lagrangian analysis from the RR and integrated over the sink, while the PRE is obtained from CRU data. The scale is in mm day ${ }^{-1}$ for both fields.

In all the graphics, the first and last month are determined considering an interval of two months before the onset and after the dismissal of the episode. This information is also provided in the list of the episodes available in item 3 .

Taking the 2008/09 episode over the SSA RR as an example of this analysis, Fig. 6a shows the predominance of negative PRE anomalies over the SSA RR during the event, reaching a peak in April 2009. Positive AED anomalies prevailed over the SSA RR during the episode, being more intense in November 2008. The moisture uptake over the sources (Fig. 6b) reduced from September to November 2008, mainly over the SSA RR. However, it increased from December 2008 to April 2009. The moisture supply accumulated from all sources into the SSA RR reduced during the episode, particularly from the TER and SSA RR up to April 2009 (Fig. 6c). Results from Fig. 6 suggest that April 2009 was a key month for this episode, when the most intense negative anomalies of PRE occurred over the SSA RR, associated with the most negative moisture supply values (mainly from the TER and SSA). However, the anomalies in the moisture uptake and supply reduced in May.

TABLE 3. Pearson correlation coefficient between the time series of moisture supply from the SSA RR into its remote terrestrial sink, and PRE over its sink. The value is significant at the $99 \%$ confidence level according to the Student's $t$ test. Data sources: CRU TS 3.24.0I for PRE, and moisture supply from the Lagrangian analysis.

PRE sink

Moisture supply

0.280
Figure $6 \mathrm{~d}$ shows how the moisture transport from the SSA RR into its sink was affected during this episode. Reduced moisture supply from the SSA RR and negative precipitation anomalies prevailed over the sink from January 2009 onward, and the peak in both anomalies occurred in February 2009.

Item 5: Correlation analysis between the anomalies of Lagrangian analysis components and the SPEI-I time series for the RR during 1980-2015. In this item, a climatological perspective of the relationship between meteorological droughts over the RRs and the components of the Lagrangian analysis is provided. The joint linear variability between the SPEI-1 time series for the RR and anomalies analyzed in item 4 is investigated through Pearson correlation analysis for 1980-2015.

The results are shown in two tables, as illustrated here for the SSA RR example, and the values significant at the $99 \%$ confidence level, according to the Student's $t$ test, are emphasized in italics.

The Pearson correlation coefficients between moisture uptake anomalies over the sources, as well as in the moisture supply from the sources into the RR, and the SPEI-1 for RR, are shown in the first table of item 5. With regard to the SSA RR (Table 2), results show a higher joint linear temporal variability between the SPEI-1 and the moisture supply from both terrestrial sources (local SSA RR and external TER) with coefficients higher than 0.5 . The second table in this item shows the Pearson correlation coefficients between the time series of moisture supply from the RR to its remote terrestrial sink, as well as PRE over sink. For the SSA RR (Table 3), the coefficient is 0.28 .

FINAL REMARKS. The purpose of the catalog described in this paper is to contribute toward a deeper understanding of the climate regions defined in the IPCC and considered as reference, particularly in climate change studies, by the scientific community, not only by the identification of drought episodes 
on several time scales during the last three decades, but also by an identification of the respective major climatological moisture sources and sinks and by an analysis of the moisture transport anomalies associated with the selected sources/sinks during the most severe meteorological drought episodes. The moisture analysis, developed through a Lagrangian approach, is organized in two parts: the first highlights the role of the region as a receptor and source of moisture under a climatic perspective, while the second one analyzes variations in the moisture transport during a case study of a significant meteorological drought. Although performed for just one case, this analysis serves as an attempt to illustrate how the moisture transport impacted the region during extreme conditions. The linear correlation analysis shown in item 5 might provide some climatic perspective of the relationship between the moisture supply from the sources and the dry/wet conditions over a target region. An integrated analysis considering the different mechanisms would be too complex for an article like this in which a number of episodes are identified at the global scale and the anomalies in the moisture transport processes are showed. Knowing the effective moisture source-sink relationships is useful to elucidate how sensitive precipitation of a given region may be to changes in the moisture transport from a remote area, and this information is of key importance to both present and future climate studies.

ACKNOWLEDGMENTS. We are grateful to the financial support from the Spanish Government (Ministerio de Economía, Industria y Competitividad) and the European Regional Development Fund of the European Commission (in Spanish, FEDER) through the SETH project (CGL201460849-JIN). The Ph.D. Fellowship of Milica Stojanovic is supported by the European Commission under the Erasmus Mundus project Green-Tech-WB: Smart and Green technologies for innovative and sustainable societies in Western Balkans (551984-EM-1-2014-1-ES-ERA MundusEMA2). This work was partially supported by Xunta de Galicia under Project ED431C 2017/64-GRC "Programa de Consolidación e Estruturación de Unidades de Investigación Competitivas (Grupos de Referencia Competitiva)". We would also like to thank the IMDROFLOOD project financed by the Water Works 2014 co-funded call of the European Commission. Thanks to the Editor and the anonymous reviewers for their constructive commentaries.

\section{REFERENCES}

Aceituno, P., M. Bidegain, J. Quintana, M. Skansi, and M. Rusticucci, 2009: Southern South America [in
"State of the Climate in 2008"]. Bull. Amer. Meteor. Soc., 90 (8), S136-S137, https://doi.org/10.1175 /BAMS-90-8-StateoftheClimate.

Allen, M. R., and W. J. Ingram, 2002: Constraints on future changes in climate and the hydrological cycle. Nature, 419, 228-232, https://doi.org/10.1038 /nature01092.

Allen, R. G., L. S. Pereira, D. Raes, and M. Smith, 1998: Crop evapotranspiration: Guidelines for computing crop water requirements. FAO Irrigation and Drainage Paper 56, 300 pp., www.fao.org/docrep/X0490E /X0490E00.htm.

Barros, V., R. Clarke, and P. S. Dias, Eds., 2006: Climate Change in the La Plata Basin. Inter-American Institute for Global Change Research, 219 pp.

Beguería, S., S. M. Vicente-Serrano, F. Reig, and B. Latorre, 2014: Standardized precipitation evapotranspiration index (SPEI) revisited: Parameter fitting, evapotranspiration models, tools, datasets and drought monitoring. Int. J. Climatol., 34, 3001-3023, https://doi.org/10.1002/joc.3887.

Bidegain, M., M. Skansi, O. Penalba, J. Quintana, and P. Aceituno, 2010: Southern South America [in "State of the Climate in 2009"]. Bull. Amer. Meteor. Soc., 91 (7), S150-S152, https://doi.org/10.1175/BAMS -91-7-StateoftheClimate.

Bless, A. E., F. Colin, A. Crabit, N. Devaux, O. Philippon, and S. Follain, 2018: Landscape evolution and agricultural land salinization in coastal area: A conceptual model. Sci. Total Environ., 625, 647-656, https:// doi.org/10.1016/j.scitotenv.2017.12.083.

Brubaker, K. L., D. Entekhabi, and P. Eagleson, 1993: Estimation of continental precipitation recycling. J. Climate, 6, 1077-1089, https://doi.org/10.1175/1520 -0442(1993)006<1077:EOCPR>2.0.CO;2.

Carbone, M. E., M. C. Piccolo, and B. V. Scian, 2004: Análisis de los periodos secos y húmedos en la cuenca del Arroyo Claromecó, Argentina. Pap. Geogr., 40, 25-36.

—, C. F. Fornerón, and M. C. Piccolo, 2015: Impacto de los eventos de sequía en la región de la cuenca hidrográfica de la laguna Sauce Grande (Provincia de Buenos Aires, Argentina). Invest. Geogr., 63, 131-142.

Castillo, R., R. Nieto, A. Drumond, and L. Gimeno, 2014: Estimating the temporal domain when the discount of the net evaporation term affects the resulting net precipitation pattern in the moisture budget using a 3-D Lagrangian approach. PLOS ONE, 9, e99046, https://doi.org/10.1371/journal.pone .0099046 .

Cherchi, A., A. Carril, C. Menéndez, and L. Zamboni, 2014: La Plata Basin precipitation variability in 
spring: Role of remote SST forcing as simulated by GCM experiments. Climate Dyn., 42, 219-236, https://doi.org/10.1007/s00382-013-1768-y.

Coplen, T. B., P. J. Neiman, A. B. White, J. M. Landwehr, F. M. Ralph, and M. D. Dettinger, 2008: Extreme changes in stable hydrogen isotopes and precipitation characteristics in a landfalling Pacific storm. Geophys. Res. Lett., 35, L21808, https://doi .org/10.1029/2008GL035481.

Cullather, R. I., D. H. Bromwich, and M. C. Serreze, 2000: The atmospheric hydrologic cycle over the Arctic Basin from reanalyses. Part I: Comparison with observations and previous studies, J. Climate, 13, 923-937, https://doi.org/10.1175/1520-0442 (2000)013<0923:TAHCOT >2.0.CO;2.

Dai, A., 2011: Characteristics and trends in various forms of the Palmer drought severity index during 1900-2008. J. Geophys. Res., 116, D12115, https://doi .org/10.1029/2010JD015541.

- , and T. Zhao, 2017: Uncertainties in historical changes and future projections of drought. Part I: Estimates of historical drought changes. Climatic Change, 144, 519-533, https://doi.org/10 .1007/s10584-016-1705-2.

D’Ambrosio, G. T., V. Y. Bohn, and M. C. Piccolo, 2013: Evaluación de la sequía 2008-2009 en el oeste de la Región Pampeana. Cuad. Geogr., 52, 29-45.

Dee, D. P., and Coauthors, 2011: The ERA-Interim reanalysis: Configuration and performance of the data assimilation system. Quart. J. Roy. Meteor. Soc., 137, 553-597, https://doi.org/10.1002/qj.828.

Diaz, A. F., C. D. Studzinski, and C. R. Mechoso, 1998: Relationships between precipitation anomalies in Uruguay and southern Brazil and sea surface temperature in the Pacific and Atlantic Oceans. J. Climate, 11, 251-271, https://doi.org/10.1175/1520 -0442(1998)011<0251:RBPAIU>2.0.CO;2.

Dirmeyer, P. A., and K. L. Brubaker, 2007: Characterization of the global hydrologic cycle from a back-trajectory analysis of atmospheric water vapor. J. Hydrometeor., 8, 20-37, https://doi.org/10.1175 /JHM557.1.

Drumond, A., R. Nieto, L. Gimeno, and T. Ambrizzi, 2008: A Lagrangian identification of major sources of moisture over central Brazil and La Plata Basin. J. Geophys. Res., 113, D14128, https://doi.org /10.1029/2007JD009547.

_, J. Marengo, T. Ambrizzi, R. Nieto, L. Moreira, and L. Gimeno, 2014: The role of the Amazon Basin moisture in the atmospheric branch of the hydrological cycle: A Lagrangian analysis. Hydrol. Earth Syst. Sci., 18, 2577-2598, https://doi.org/10.5194 /hess-18-2577-2014.
_- R. Nieto, and L. Gimeno, 2016: A Lagrangian approach for investigating anomalies in the moisture transport during drought episodes. Cuad. Invest. Geogr., 42, 113-125, https://doi.org/10.18172 /cig. 2925.

-, L. Gimeno, R. Nieto, R. M. Trigo, and S. M. Vicente-Serrano, 2017: Drought episodes in the climatological sinks of the Mediterranean moisture source: The role of moisture transport. Global Planet. Change, 151, 4-14, https://doi.org/10.1016/j.gloplacha .2016.12.004.

Feng, S., Q. Hu, and J. Robert, 2011: Influence of Atlantic sea surface temperatures on persistent drought in North America. Climate Dyn., 37, 569-586, https:// doi.org/10.1007/s00382-010-0835-x.

Forster, C., A. Stohl, and P. Seibert, 2007: Parameterization of convective transport in a Lagrangian particle dispersion model and its evaluation. J. Appl. Meteor. Climatol., 46, 403-422, https://doi.org/10.1175 /JAM2470.1.

Fu, Q., and S. Feng, 2014: Responses of terrestrial aridity to global warming. J. Geophys. Res. Atmos., 119, 7863-7875, https://doi.org/10.1002/2014JD021608.

García-Herrera, R., D. Paredes, R. M. Trigo, I. F. Trigo, E. Hernandez, D. Barriopedro, and M. A. Mendes, 2007: The outstanding 2004/05 drought in the Iberian Peninsula: Associated atmospheric circulation. J. Hydrometeor., 8, 483-498, https://doi.org/10.1175 /JHM578.1.

Gimeno, L., A. Drumond, R. Nieto, R. M. Trigo, and A. Stohl, 2010: On the origin of continental precipitation. Geophys. Res. Lett., 37, L13804, https://doi.org /10.1029/2010GL043712.

— , and Coauthors, 2012: Oceanic and terrestrial sources of continental precipitation. Rev. Geophys., 50, RG4003, https://doi.org/10.1029/2012RG000389.

- , R. Nieto, A. Drumond, R. Castillo, and R. M. Trigo, 2013: Influence of the intensification of the major oceanic moisture sources on continental precipitation. Geophys. Res. Lett., 40, 1443-1450, https:// doi.org/10.1002/grl.50338.

Gómez-Hernández, M., A. Drumond, L. Gimeno, and R. Garcia-Herrera, 2013: Variability of moisture sources in the Mediterranean region during the period 1980-2000. Water Resour. Res., 49, 6781-6794, https://doi.org/10.1002/wrcr.20538.

Hanel, M., O. Rakovec, Y. Markonis, P. Máca, L. Samaniego, J. Kysely, and R. Kumar, 2018: Revisiting the recent European droughts from a long-term perspective. Sci. Rep., 8, 9499, https://doi.org/10.1038 /s41598-018-27464-4.

Harris, I., P. D. Jones, T. J. Osborn, and D. H. Lister, 2014: Updated high-resolution grids of monthly climatic 
observations-The CRU TS3.10 dataset. Int. J. Climatol., 34, 623-642, https://doi.org/10.1002/joc.3711.

Hayes, M., M. Svoboda, N. Wall, and M. Widhalm, 2011: The Lincoln Declaration on Drought Indices: Universal meteorological drought index recommended. Bull. Amer. Meteor. Soc., 92, 485-488, https://doi .org/10.1175/2010BAMS3103.1.

Heim, R. R., 2002: A review of twentieth-century drought indices used in the United States. Bull. Amer. Meteor. Soc., 83, 1149-1165, https://doi.org/10 $.1175 / 1520-0477-83.8 .1149$.

Hirschi, M., and Coauthors, 2011: Observational evidence for soil-moisture impact on hot extremes in southeastern Europe. Nat. Geosci., 4, 17-21, https:// doi.org/10.1038/ngeo1032.

IPCC, 2014: Climate Change 2014: Synthesis Report. IPCC, 151 pp., www.ipcc.ch/report/ar5/syr/.

Kannenberg, S., J. T. Maxwell, N. Pederson, L. D’Orangeville, D. L. Ficklin, and, R. P. Phillips, 2018: Drought legacies are dependent on water table depth, wood anatomy and drought timing across the eastern US. Ecol. Lett., 22, 119-127, https://doi.org/10.1111 /ele.13173.

Kingston, D. G., J. H. Stagge, L. M. Tallaksen, and D. M. Hannah, 2015: European-scale drought: Understanding connections between atmospheric circulation and meteorological drought indices. J. Climate, 28, 505-516, https://doi.org/10.1175/JCLI-D-14-00001.1.

Knippertz, P., H. Wernli, and G. Gläser, 2013: A global climatology of tropical moisture exports. J. Climate, 26, 3031-3045, https://doi.org/10.1175/JCLI-D -12-00401.1.

Liu, W., X. Gou, J. Li, Y. Huo, M. Yang, and W. Lin, 2018: Separating temperature from precipitation signals encoded in tree-ring widths over the past millennium on the northeastern Tibetan Plateau, China. Quat. Sci. Rev., 193, 159-169, https://doi.org/10.1016/j .quascirev.2018.06.008.

Liu, Z., G. Lu, H. He, Z. Wu, and J. He, 2017: Anomalous features of water vapor transport during severe summer and early fall droughts in southwest China. Water, 9, 244, https://doi.org/10.3390/w9040244.

Lloyd-Hughes, B., 2014: The impracticality of a universal drought definition. Theor. Appl. Climatol., 117, 607-611, https://doi.org/10.1007/s00704-013-1025-7.

Lorenz, C., and H. Kunstmann, 2012: The hydrological cycle in three state-of-the-art reanalyses: Intercomparison and performance analysis. J. Hydrometeor., 13, 1397-1420, https://doi.org/10.1175/JHM-D $-11-088.1$.

Lorenzo-Lacruz, J., S. M. Vicente-Serrano, J. C. Gonzalez-Hidalgo, J. L. López-Moreno, and N. Cortesi, 2013: Hydrological drought response to meteorological drought in the Iberian Peninsula. Climate Res., 58, 117-131, https://doi.org/10.3354 /cr01177.

Marengo, J. A., and J. S. Espinoza, 2016: Extreme seasonal droughts and floods in Amazonia: Causes, trends and impacts. Int. J. Climatol., 36, 1033-1050, https://doi.org/10.1002/joc.4420.

_ , J. Baez, and J. Ronchail, 2009: Tropical South America east of the Andes [in "State of the Climate in 2008”]. Bull. Amer. Meteor. Soc., 90 (8), S134S136, https://doi.org/10.1175/BAMS-90-8-Stateofthe Climate.

, J. Ronchail, J. Baez, and L. M. Alves, 2010: Tropical South America east of the Andes [in "State of the Climate in 2009"]. Bull. Amer. Meteor. Soc., 91 (7), S148-S150, https://doi.org/10.1175/BAMS-91 -7-StateoftheClimate.

McKee, T. B., N. J. Doesken, and J. Kleist, 1993: The relationship of drought frequency and duration to time scales. Preprints, Eighth Conf. on Applied Climatology, Anaheim, CA, Amer. Meteor. Soc., 179-184.

Miralles, D. G., P. Gentine, S. I. Seneviratne, and A. J. Teuling, 2019: Land-atmospheric feedbacks during droughts and heatwaves: State of the science and current challenges. Ann. N. Y. Acad. Sci., 1436, 19-35, https://doi.org/10.1111/nyas.13912.

Mishra, A. K., and V. P. Singh, 2010: A review of drought concepts. J. Hydrol., 391, 202-216, https:// doi.org/10.1016/j.jhydrol.2010.07.012.

Mukherjee, S., A. Mishra, and K. E. Trenberth, 2018: Climate change and drought: A perspective on drought indices. Curr. Climate Change Rep., 4, 145-163, https://doi.org/10.1007/s40641-018-0098-x.

Müller, O. V., E. H. Berbery, D. Alcaraz-Segura, and M. B. Ek, 2014: Regional model simulations of the 2008 drought in southern South America using a consistent set of land surface properties. J. Climate, 27, 6754-6778, https://doi.org/10.1175/JCLI -D-13-00463.1.

NCAR, 2018: CRU TS gridded precipitation and other meteorological variables since 1901. Climate Data Guide, accessed 16 November 2018, https://climatedataguide .ucar.edu/climate-data/cru-ts-gridded-precipitation -and-other-meteorological-variables-1901.

Nieto, R., R. Castillo, A. Drumond, and L. Gimeno, 2014: A catalog of moisture sources for continental climatic regions. Water Resour. Res., 50, 5322-5328, https://doi.org/10.1002/2013WR013901.

Nogués-Paegle, J., and Coauthors, 2002: Progress in Pan American CLIVAR research: Understanding the South American monsoon. Meteorologica, 27, 3-32. Numaguti, A., 1999: Origin and recycling processes of precipitating water over the Eurasian continent: 
Experiments using an atmospheric general circulation model. J. Geophys. Res., 104, 1957-1972, https:// doi.org/10.1029/1998JD200026.

Onyutha, C., 2018: Trends and variability in African long-term precipitation. Stochastic Environ. Res. Risk Assess., 32, 2721-2739, https://doi.org/10.1007 /s00477-018-1587-0.

Otkin, J. A., M. Svoboda, E. D. Hunt, T. W. Ford, M. C. Anderson, C. Hain, and B. Basara, 2017: Flash droughts: A review and assessment of the challenges imposed by rapid-onset droughts in the United States. Bull. Amer. Meteor. Soc., 99, 911-919, https:// doi.org/10.1175/BAMS-D-17-0149.1.

Peña-Gallardo, M., S. M. Vicente-Serrano, F. DomínguezCastro, S. Quiring, M. Svoboda, S. Beguería, and J. Hannaford, 2018: Effectiveness of drought indices in identifying impacts on major crops across the USA. Climate Res., 75, 221-240, https://doi.org/10.3354 /cr01519.

Raymond, F., A. Ullmann, P. Camberlin, B. Oueslati, and P. Drobinski, 2018: Atmospheric conditions and weather regimes associated with extreme winter dry spells over the Mediterranean basin. Climate Dyn., 50, 4437-4453, https://doi.org/10.1007/s00382-017-3884-6.

Redmond, K. T., 2002: The depiction of drought: A commentary. Bull. Amer. Meteor. Soc., 83, 1143-1147, https://doi.org/10.1175/1520-0477-83.8.1143.

Rivera, J. A., and O. C. Penalba, 2014: Trends and spatial patterns of drought affected area in southern South America. Climate, 2, 264-278, https://doi .org/10.3390/cli2040264.

Salah, Z., R. Nieto, A. Drumond, L. Gimeno, and S. M. Vicente-Serrano, 2018: A Lagrangian analysis of the moisture budget over the Fertile Crescent during two intense drought episodes. J. Hydrol., 560, 382-395, https://doi.org/10.1016/j.jhydrol.2018.03.021.

Scarchilli, C., M. Frezzotti, and P. M. Ruti, 2011: Snow precipitation at four ice core sites in East Antarctica: Provenance, seasonality and blocking factors. Climate Dyn., 37, 2107-2125, https://doi.org/10.1007 /s00382-010-0946-4.

Schubert, S. D., H. Wang, R. D. Koster, M. J. Suarez, and P. Ya. Groisman, 2014: Northern Eurasian heat waves and droughts. J. Climate, 27, 3169-3207, https://doi.org /10.1175/JCLI-D-13-00360.1.

— - and Coauthors, 2016: Global meteorological drought: A synthesis of current understanding with a focus on SST drivers of precipitation deficits. $J$. Climate, 29, 3989-4019, https://doi.org/10.1175/JCLI -D-15-0452.1.

Sherwood, S., and Q. Fu, 2014: A drier future? Science, 343, 737-739, https://doi.org/10.1126/science .1247620 .
Sodemann, H., C. Schwierz, and H. Wernli, 2008: Interannual variability of Greenland winter precipitation sources: Lagrangian moisture diagnostic and North Atlantic Oscillation influence. J. Geophys. Res., 113, D03107, https://doi.org/10.1029/2007JD008503.

Sörensson, A. A., and C. G. Menéndez, 2011: Summer soil-precipitation coupling in South America. Tellus, 63A, 56-68, https://doi.org/10.1111/j.1600 $-0870.2010 .00468 . x$.

Sorí, R., R. Nieto, S. M. Vicente-Serrano, A. Drumond, and L. Gimeno, 2017: A Lagrangian perspective of the hydrological cycle in the Congo River basin. Earth Syst. Dyn., 8, 653-675, https://doi.org/10.5194 lesd-8-653-2017.

Spinoni, J., G. Naumann, H. Carrao, P. Barbosa, and J. Vogt, 2014: World drought frequency, duration, and severity for 1951-2010. Int. J. Climatol., 34, 2792-2804, https://doi.org/10.1002/joc.3875.

Stohl, A., and P. James, 2004: A Lagrangian analysis of the atmospheric branch of the global water cycle. Part I: Method description, validation, and demonstration for the August 2002 flooding in central Europe. J. Hydrometeor., 5, 656-678, https://doi.org/10.1175/1525 -7541(2004)005<0656:ALAOTA >2.0.CO;2.

— and - 2005: A Lagrangian analysis of the atmospheric branch of the global water cycle. Part II: Moisture transports between Earth's ocean basins and river catchments. J. Hydrometeor., 6, 961-984, https://doi.org/10.1175/JHM470.1.

- C. Forster, A. Frank, P. Seibert, and G. Wotawa, 2005: Technical note: The Lagrangian particle dispersion model FLEXPART version 6.2. Atmos. Chem. Phys., 5, 2461-2474, https://doi.org/10.5194 /acp-5-2461-2005.

Stojanovic, M., A. Drumond, R. Nieto, and L. Gimeno, 2018a: Anomalies in moisture supply during the 2003 drought event in Europe: A Lagrangian analysis. Water, 10, 467, https://doi.org/10.3390/w10040467.

— _ _ - , and _ 2018b: Variations in moisture supply from the Mediterranean Sea during meteorological drought episodes over central Europe. Atmosphere, 9, 278, https://doi.org/10.3390/atmos9070278.

Sun, Q., C. Miao, Q. Duan, H. Ashouri, S. Sorooshian, and K.-L. Hsu, 2018: A review of global precipitation data sets: Data sources, estimation, and intercomparisons. Rev. Geophys., 56, 79-107, https://doi .org/10.1002/2017RG000574.

Tan, C., J. Yang, and M. Li, 2015: Temporal-spatial variation of drought indicated by SPI and SPEI in Ningxia Hui Autonomous Region, China. Atmosphere, 6, 1399-1421, https://doi.org/10.3390/atmos6101399.

Trenberth, K. E., 1998: Atmospheric moisture residence times and cycling: Implications for rainfall rates 
and climate change. Climatic Change, 39, 667-694, https://doi.org/10.1023/A:1005319109110.

—, J. T. Fasullo, and J. Mackaro, 2011: Atmospheric moisture transports from ocean to land and global energy flows in reanalyses. J. Climate, 24, 4907-4924, https://doi.org/10.1175/2011JCLI4171.1.

Trigo, R. M., and Coauthors, 2013: The record winter drought of 2011-12 in the Iberian Peninsula [in "Explaining Extreme Events of 2012 from a Climate Perspective"]. Bull. Amer. Meteor. Soc., 94 (9), S41S45, https://doi.org/10.1175/BAMS-D-13-00085.1.

Vázquez, M., R. Nieto, A. Drumond, and L. Gimeno, 2016: Moisture transport into the Arctic: Source-receptor relationships and the roles of atmospheric circulation and evaporation. J. Geophys. Res. Atmos., 121, 13493-13 509, https://doi.org/10.1002/2016JD025400.

Vecchi, G. A., and B. J. Soden, 2007: Global warming and the weakening of the tropical circulation. J. Climate, 20, 4316-4340, https://doi.org/10.1175/JCLI4258.1.

Vicente-Serrano, S. M., 2016: Foreword: Drought complexity and assessment under climate change conditions. Cuad. Invest. Geogr., 42, 7-11, https:// doi.org/10.18172/cig.2961.

— , and S. Beguería, 2016: Short communication comment on "candidate distributions for climatological drought indices (SPI and SPEI)" by James H. Stagge et al. Int. J. Climatol., 36, 2120-2131, https://doi.org /10.1002/joc.4474.

— - , and J. I. López-Moreno, 2010: A multiscalar drought index sensitive to global warming: The standardized precipitation evapotranspiration index. J. Climate, 23, 1696-1718, https://doi .org/10.1175/2009JCLI2909.1.

—, J. I. López-Moreno, L. Gimeno, R. Nieto, E. MoránTejeda, J. Lorenzo-Lacruz, S. Beguería, and C. AzorinMolina, 2011: A multiscalar global evaluation of the impact of ENSO on droughts. J. Geophys. Res., 116, D20109, https://doi.org/10.1029/2011JD016039.
— indices for ecological, agricultural and hydrological applications. Earth Interact., 16, https://doi.org/10.1175 /2012EI000434.1.

— drought time-scales across global land biomes. Proc. Natl. Acad. Sci. USA, 110, 52-57, https://doi.org/10 $.1073 /$ pnas.1207068110.

—, G. Van der Schrier, S. Beguería, C. AzorinMolina, and J. I. Lopez-Moreno, 2015: Contribution of precipitation and reference evapotranspiration to drought indices under different climates. J. Hydrol., 526, 42-54, https://doi.org/10.1016/j.jhydrol.2014 .11 .025 .

Viglizzo, E. F., and F. C. Frank, 2006: Ecological interactions, feedbacks, thresholds and collapses in the Argentine Pampas in response to climate and farming during the last century. Quat. Int., 158, 122-126, https://doi.org/10.1016/j.quaint.2006.05.022.

Wilhite, D. A., and M. H. Glantz, 1985: Understanding the drought phenomenon: The role of definitions. Water Int., 10, 111-120, https://doi.org/10.1080 /02508068508686328.

— CRC Press, 542 pp.

WMO, 2012: Standardized precipitation index user guide. WMO-1090, 24 pp., www.wmo.int/pages /prog/wcp/agm/publications/agm_proceedings.php.

Zambreski, T. Z., X. Lin, R. M. Aiken, G. J. Kluitenberg, and R. A. Pielke, 2018: Identification of hydroclimate subregions for seasonal drought monitoring in the U.S. Great Plains. J. Hydrol., 567, 370-381, https:// doi.org/10.1016/j.jhydrol.2018.10.013.

Zhao, Y., and Coauthors, 2018: Comparing empirical and survey-based yield forecasts in a dryland agroecosystem. Agric. For. Meteor., 262, 147-156, https:// doi.org/10.1016/j.agrformet.2018.06.024. 